\title{
Comment on "Clinical Comparisons of Two Free Light Chain Assays to Immunofixation Electrophoresis for Detecting Monoclonal Gammopathy"
}

\author{
Antony R. Parker, Oscar Berlanga, and Stephen Harding \\ Binding Site Group Limited, 15 Calthorpe Road, Birmingham B15 1QT, UK \\ Correspondence should be addressed to Oscar Berlanga; oscar.berlanga@bindingsite.co.uk
}

Received 15 October 2014; Accepted 5 March 2015

Academic Editor: Robert Baiocchi

Copyright (C) 2015 Antony R. Parker et al. This is an open access article distributed under the Creative Commons Attribution License, which permits unrestricted use, distribution, and reproduction in any medium, provided the original work is properly cited.

The recent publication by Kim et al. [1] compares the performance of two serum free light chain (sFLC) assays, the polyclonal antibody based Freelite and the monoclonal antibody based N-Latex-FLC. We welcome the opportunity to comment on the design of the study and interpretation of results.

Serum and urine electrophoresis can be used to identify monoclonal gammopathy (MG) patients with gross intact monoclonal immunoglobulin or free light chain production. However, electrophoresis assays are insensitive for the detection of patients with AL amyloidosis and nonsecretory multiple myeloma (NSMM). The introduction of the Freelite assay in 2001 [2] improved the sensitivity for detection of patients with monoclonal free light chain production. This improved sensitivity has resulted in the inclusion of Freelite in international guidelines [3-5] for screening, diagnosis, and monitoring of monoclonal gammopathies. Recently, assays utilising monoclonal antibodies for the measurement of serum free light chains have become available. The assays are calibrated to Freelite, but so far there is a paucity of data comparing the clinical performance of the assays.

Kim et al. analysed samples from $63 \mathrm{MG}(n=100$ samples) and 57 non-MG ( $n=57$ samples) patients. Both kappa and lambda N-Latex-FLC are calibrated to the Freelite assays [6] and therefore it is not surprising that there is concordance with results in a normal population. However, we believe there are too few clinical samples from patients with light chain multiple myeloma (LCMM) (10/63) and AL amyloidosis $(2 / 63)$ for Kim et al. to make a reliable clinical comparison.

There were 17 discordant results in this study (13 MG and 4 non-MG patients). It would have been informative if the authors had presented the performance of the assays in the different groups of monoclonal gammopathy patients, particularly in those with LCMM and AL amyloidosis. Specifically in LCMM populations previous studies with the monoclonal antibody based N-Latex-FLC test have failed to identify all patients [6-8]. By contrast in sixteen independent studies, including samples from 682 LCMM patients, an abnormal $\kappa / \lambda$ sFLC ratio using the Freelite assay identified $100 \%$ samples (Table 1) [9-25]. One study [26] reported a LCMM patient missed by Freelite; however the sample was correctly identified when reanalysed using the same batch of reagent, indicating a previous analytical error (personal communication). To truly understand the concordance between the assays larger studies are required in clinically relevant populations including patients with AL amyloidosis, LCMM, and NSMM. In addition, there has only been a single study comparing the assays in patient with acute kidney injury [27].

$4 / 57$ non-MG patients had an abnormal $\kappa / \lambda$ sFLC ratio using the Freelite assay but had normal ratios using the N-Latex-FLC assay. These patients had disorders (chronic kidney disease, chronic obstructive pulmonary disease, iron deficiency anaemia, and systemic lupus erythematosus) that 
TABLE 1: Publications reporting detection of LCMM patients with Freelite.

\begin{tabular}{|c|c|c|c|c|}
\hline Study (year) & Patient numbers & $\kappa$ & $\lambda$ & $\kappa / \lambda$ ratio abnormal \\
\hline Bradwell et al. 2003 [9] & 224 & 123 & 101 & $100 \%$ \\
\hline Drayson et al. 2009 [10] & 223 & NA & NA & $100 \%$ \\
\hline van Rhee et al. 2007 [11] & 49 & NA & NA & $100 \%$ \\
\hline Kraj et al. 2011 [12] & 37 & 21 & 16 & $100 \%$ \\
\hline Abraham et al. 2002 [13] & 28 & 9 & 19 & $100 \%$ \\
\hline Avet-Loiseau et al. $2011[14,15]$ & 25 & 14 & 11 & $100 \%$ \\
\hline Kang et al. 2005 [16] & 23 & 14 & 9 & $100 \%$ \\
\hline Nowrousian et al. 2005 [17] & 17 & NA & NA & $100 \%$ \\
\hline Hutchison et al. 2008 [18] & 13 & 5 & 8 & $100 \%$ \\
\hline Mösbauer et al. 2007 [19] & 9 & 5 & 4 & $100 \%$ \\
\hline Piehler et al. 2008 [20] & 7 & 4 & 3 & $100 \%$ \\
\hline Harding et al. 2009 [21] & 7 & 4 & 3 & $100 \%$ \\
\hline Lebovic et al. 2007 [22] & 7 & 3 & 4 & $100 \%$ \\
\hline Giarin et al. 2006 [23] & 6 & NA & NA & $100 \%$ \\
\hline Wolff et al. 2007 [24] & 5 & NA & NA & $100 \%$ \\
\hline Dogaru et al. 2011 [25] & 2 & 0 & 2 & $100 \%$ \\
\hline
\end{tabular}

have previously been reported to cause a perturbation of the $\kappa / \lambda$ sFLC ratio due to poor renal function, inflammation, or immune stimulation [28-30]. In patients with renal impairment FLC removal becomes increasingly dependent on the reticuloendothelial system. Unlike renal clearance reticuloendothelial clearance is not influenced by size of the light chains [31]; therefore the production rate of kappa FLC (approximately $2 \mathrm{x}$ that of lambda) exerts an influence on the $\kappa / \lambda$ FLC ratio. Whilst there have previously been reports highlighting the difference in the performance of the $\mathrm{N}$ Latex-FLC assay in patients with impaired renal function, there has been no physiological explanation for this performance [32].

The quantitative assessment of free light chains by Freelite is an important laboratory test. An abnormal ratio can be used as part of an algorithm to risk stratifying monoclonal gammopathy of undetermined significance patients. Furthermore, a ratio of $>100$ with a monoclonal free light chain concentration $>100 \mathrm{mg} / \mathrm{L}$ was recently included in the diagnostic algorithm for patients with multiple myeloma, and an abnormal ratio is useful in understanding the depth of response in patients during the course of their disease [33-35]. Given the reliance upon the numerical values we believe there is a strong requirement for better quantitative concordance between the assays, and clearly the role of Freelite in diagnosis, stratification, and response cannot be transferred to the N-Latex-FLC assay.

In summary, sample selection in this study limits interpretation but supports published data showing that differences exist between the polyclonal and monoclonal FLC assays.

\section{Conflict of Interests}

A. R. Parker and O. Berlanga are employees of the Binding Site Group Limited. S. Harding is a Director of the Binding Site Group Limited.

\section{References}

[1] H.-S. Kim, H. S. Kim, K.-S. Shin et al., "Clinical comparisons of two free light chain assays to immunofixation electrophoresis for detecting monoclonal gammopathy," BioMed Research International, vol. 2014, Article ID 647238, 7 pages, 2014.

[2] A. R. Bradwell, H. D. Carr-Smith, G. P. Mead et al., "Highly sensitive, automated immunoassay for immunoglobulin free light chains in serum and urine," Clinical Chemistry, vol. 47, no. 4, pp. 673-680, 2001.

[3] A. Dispenzieri, R. Kyle, G. Merlini et al., "International Myeloma Working Group guidelines for serum-free light chain analysis in multiple myeloma and related disorders," Leukemia, vol. 23, no. 2, pp. 215-224, 2009.

[4] B. G. Durie, J. L. Harousseau, J. S. Miguel et al., "International uniform response criteria for multiple myeloma," Leukemia, vol. 20, no. 9, pp. 1467-1473, 2006.

[5] R. A. Kyle and S. V. Rajkumar, "Criteria for diagnosis, staging, risk stratification and response assessment of multiple myeloma," Leukemia, vol. 23, no. 1, pp. 3-9, 2009.

[6] R. M. J. Hoedemakers, J. F. M. Pruijt, S. Hol et al., "Clinical comparison of new monoclonal antibody-based nephelometric assays for free light chain kappa and lambda to polyclonal antibody-based assays and immunofixation electrophoresis," Clinical Chemistry and Laboratory Medicine, vol. 50, no. 3, pp. 489-495, 2011.

[7] H. Te Velthuis, I. Knop, P. Stam et al., "N Latex FLC-new monoclonal high-performance assays for the determination of free light chain kappa and lambda," Clinical Chemistry and Laboratory Medicine, vol. 49, no. 8, pp. 1323-1332, 2011.

[8] R. J. Lock, R. Saleem, E. G. Roberts et al., "A multicentre study comparing two methods for serum free light chain analysis," Annals of Clinical Biochemistry, vol. 50, no. 3, pp. 255-261, 2013.

[9] A. R. Bradwell, H. D. Carr-Smith, G. P. Mead, T. C. Harvey, and M. T. Drayson, "Serum test for assessment of patients with Bence Jones myeloma," The Lancet, vol. 361, no. 9356, pp. 489491, 2003.

[10] M. T. Drayson, G. J. Morgan, G. H. Jackson et al., "A346 Prospective study of serum FLC and other M-protein assays: 
when and how to measure response?" Clinical Lymphoma and Myeloma, vol. 9, supplement 1, p. S56, 2009.

[11] F. van Rhee, V. Bolejack, K. Hollmig et al., "High serum-free light chain levels and their rapid reduction in response to therapy define an aggressive multiple myeloma subtype with poor prognosis," Blood, vol. 110, no. 3, pp. 827-832, 2007.

[12] M. Kraj, B. Kruk, R. Poglod, and A. Szczepinski, "Correlation of serum free light chain quantification with serum and urine immunofixation in monoclonal gammopathies," Haematologica, vol. 96, article 861a, 2011.

[13] R. S. Abraham, R. J. Clark, S. C. Bryant et al., "Correlation of serum immunoglobulin free light chain quantification with urinary bence jones protein in light chain myeloma," Clinical Chemistry, vol. 48, no. 4, pp. 655-657, 2002.

[14] H. Avet Loiseau, L. Mirbahai, P. Young et al., "Nephelometric measurements of $\kappa \mathrm{FLC}$ and $\lambda \mathrm{FLC}$ for monitoring light chain multiple myeloma patients," Lymphoma and Myeloma. In press.

[15] H. Avet-Loiseau, P. Young, C. Mathiot et al., "Nephelometric measurements of $\kappa$ FLC and $\lambda$ FLC for monitoring light myeloma patients," Haematologica, vol. 96, supplement 2, Article ID 0853a, 2011.

[16] S.-Y. Kang, J.-T. Suh, H.-J. Lee, H.-J. Yoon, and W.-I. Lee, "Clinical usefulness of free light chain concentration as a tumor marker in multiple myeloma," Annals of Hematology, vol. 84, no. 9, pp. 588-593, 2005.

[17] M. R. Nowrousian, D. Brandhorst, C. Sammet et al., "Serum free light chain analysis and urine immunofixation electrophoresis in patients with multiple myeloma," Clinical Cancer Research, vol. 11, no. 24, pp. 8706-8714, 2005.

[18] C. A. Hutchison, T. Plant, M. Drayson et al., "Serum free light chain measurement aids the diagnosis of myeloma in patients with severe renal failure," BMC Nephrology, vol. 9, no. 1, article $11,2008$.

[19] U. Mösbauer, F. Ayuk, H. Schieder, M. Lioznov, A. R. Zander, and N. Kröger, "Monitoring serum free light chains in patients with multiple myeloma who achieved negative immunofixation after allogeneic stem cell transplantation," Haematologica, vol. 92, no. 2, pp. 275-276, 2007.

[20] A. P. Piehler, N. Gulbrandsen, P. Kierulf, and P. Urdal, "Quantitation of serum free light chains in combination with protein electrophoresis and clinical information for diagnosing multiple myeloma in a general hospital population," Clinical Chemistry, vol. 54, no. 11, pp. 1823-1830, 2008.

[21] S. J. Harding, G. P. Mead, A. R. Bradwell, and A. M. Berard, "Serum free light chain immunoassay as an adjunct to serum protein electrophoresis and immunofixation electrophoresis in the detection of multiple myeloma and other B-cell malignancies," Clinical Chemistry and Laboratory Medicine, vol. 47, no. 3 , pp. 302-304, 2009.

[22] D. Lebovic, T. Kendall, C. Brozo et al., "Serum free light chain analysis improves monitoring of multiple myeloma patients receiving first-line therapy with the combination of Velcade, Doxil, and Dexamethasone (VDD)," Blood, vol. 110, article 2736a, 2007.

[23] M. M. Giarin, L. Giaccone, D. Caracciolo et al., "Serum free light chains (SFLC) assay: a suggestive new criteria for evaluating disease response, progression and relapse in plasma-cell disorders (PD) and a prognostic factor in monoclonal gammopathy of undetermined significance (MGUS)," Haematologica, vol. 91, Article ID PO151a, 2006.

[24] F. Wolff, C. Thiry, and D. Willems, "Assessment of the analytical performance and the sensitivity of serum free light chains immunoassay in patients with monoclonal gammopathy," Clinical Biochemistry, vol. 40, no. 5-6, pp. 351-354, 2007.

[25] M. Dogaru, V. Lazar, and D. Coriu, "Assessing the efficiency of free light chain assay in monitoring patients with multiple myeloma before and after autologous stem cell transplantation along with serum protein electrophoresis and serum protein immunofixation.", Roumanian archives of microbiology and immunology, vol. 70, no. 1, pp. 15-22, 2011.

[26] T.-D. Jeong, S. Y. Kim, S. Jang et al., "Diagnostic sensitivity of a panel of tests to detect monoclonal protein in Korean multiple myeloma patients," Clinical Chemistry and Laboratory Medicine, vol. 51, no. 8, pp. e187-e189, 2013.

[27] C. A. Hutchison, P. Cockwell, and M. Cook, "Diagnostic accuracy of monoclonal antibody based serum immunoglobulin free light chain immunoassays in myeloma cast nephropathy," BMC Clinical Pathology, vol. 12, article 12, 2012.

[28] J. M. Abadie, K. H. van Hoeven, and J. M. Wells, "Are renal reference intervals required when screening for plasma cell disorders with serum free light chains and serum protein electrophoresis?" The American Journal of Clinical Pathology, vol. 131, no. 2, pp. 166-171, 2009.

[29] S. Braber, M. Thio, B. R. Blokhuis et al., "An association between neutrophils and immunoglobulin free light chains in the pathogenesis of chronic obstructive pulmonary disease," The American Journal of Respiratory and Critical Care Medicine, vol. 185, no. 8, pp. 817-824, 2012.

[30] G. Marshall, J. Tate, and P. Mollee, "Borderline high serum free light chain $\kappa / \lambda$ ratios are seen not only in dialysis patients but also in non-dialysis-dependent renal impairment and inflammatory states," The American Journal of Clinical Pathology, vol. 132, article 309, 2009.

[31] K. E. Arfors, G. Rutili, and E. Svensjo, "Microvascular transport of macromolecules in normal and inflammatory conditions," Acta Physiologica Scandinavica, vol. 106, no. 463, pp. 93-103, 1979.

[32] J. F. M. Jacobs, R. M. Hoedemakers, E. Teunissen, and H. te Velthuis, "N latex FLC serum free light-chain assays in patients with renal impairment," Clinical Chemistry and Laboratory Medicine, vol. 52, no. 6, pp. 853-859, 2014.

[33] S. V. Rajkumar, M. A. Dimopoulos, A. Palumbo et al., "International Myeloma Working Group updated criteria for the diagnosis of multiple myeloma," The Lancet Oncology, vol. 15, no. 12, pp. e538-e548, 2014.

[34] P. Kapoor, S. K. Kumar, A. Dispenzieri et al., "Importance of achieving stringent complete response after autologous stemcell transplantation in multiple myeloma.," Journal of Clinical Oncology, vol. 31, no. 36, pp. 4529-4535, 2013.

[35] S. V. Rajkumar, R. A. Kyle, T. M. Therneau et al., "Serum free light chain ratio is an independent risk factor for progression in monoclonal gammopathy of undetermined significance," Blood, vol. 106, pp. 812-817, 2005. 


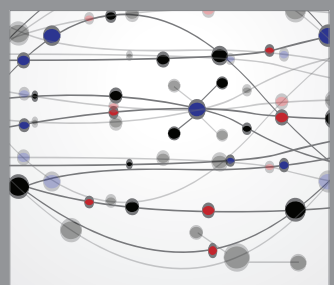

The Scientific World Journal
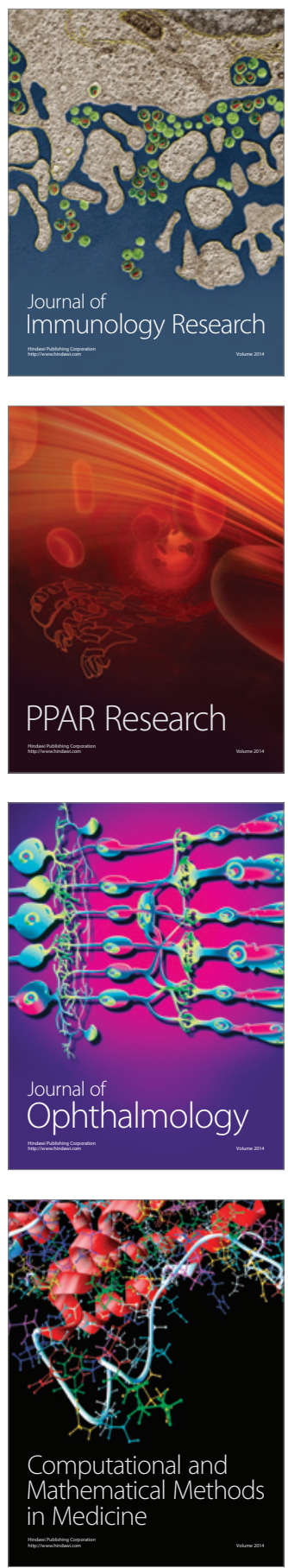

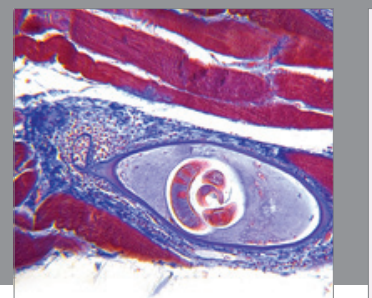

Gastroenterology

Research and Practice
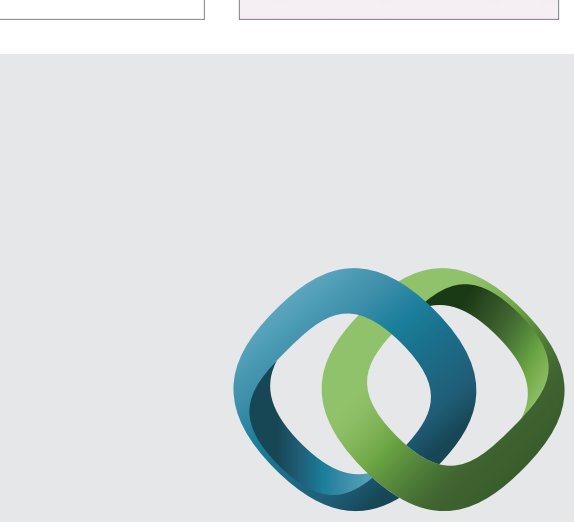

\section{Hindawi}

Submit your manuscripts at

http://www.hindawi.com
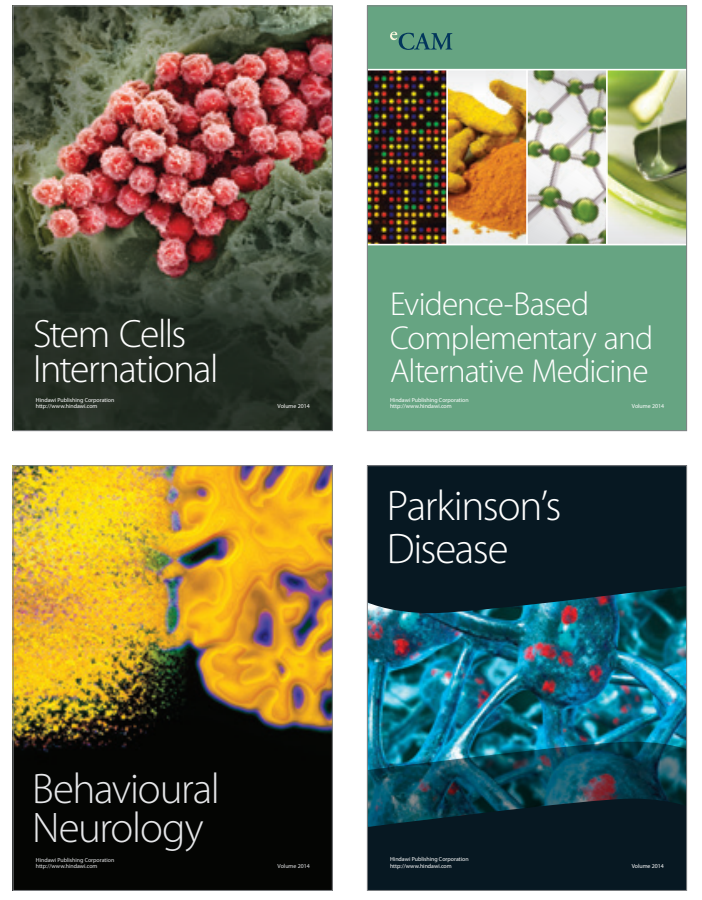
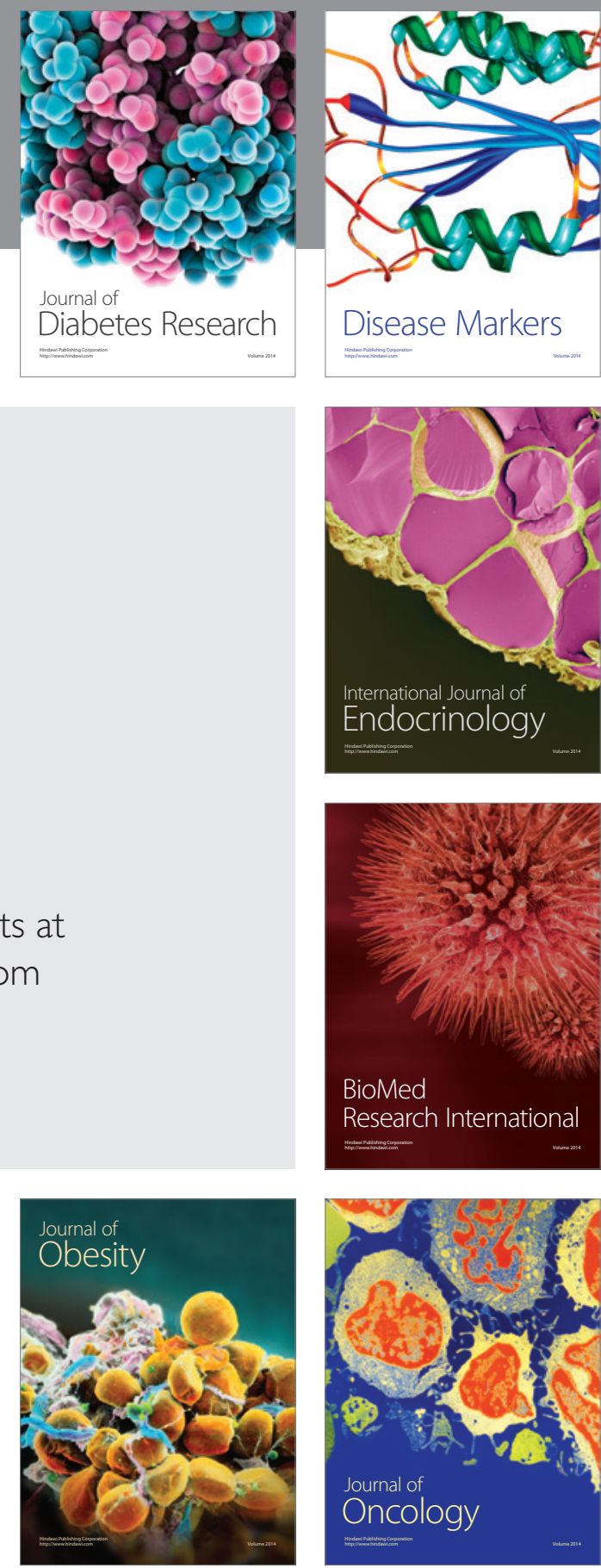

Disease Markers
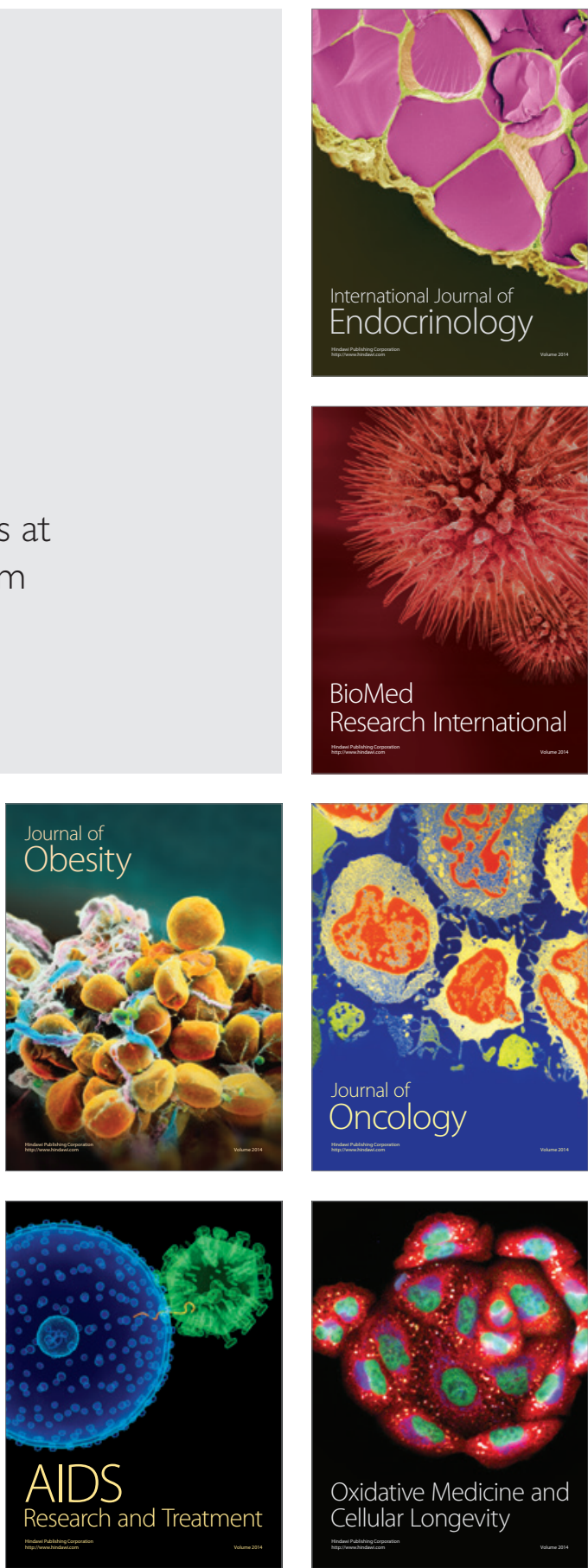